\title{
Smallholder irrigation schemes in South Africa: A review of knowledge generated by the Water Research Commission
}

\author{
W van Averbeke ${ }^{1 *}, \mathrm{~J}^{\text {Denison }}{ }^{2}$ and PNS Mnkeni ${ }^{3}$ \\ ${ }^{1}$ Centre for Organic and Smallholder Agriculture, Department of Crop Sciences, Tshwane University of Technology, \\ $P$ Bag X680, Pretoria 0001, South Africa \\ ${ }^{2}$ Department of Geography, Rhodes University, PO Box 94, Grahamstown 6140, South Africa \\ ${ }^{3}$ Department of Agronomy, University of Fort Hare, P Bag X1314, Alice 5700, South Africa
}

\begin{abstract}
The status and characteristics of the 302 smallholder irrigation schemes found in South Africa are discussed and knowledge on South African smallholder irrigation schemes generated by the Water Research Commission (WRC) over a period of nearly 20 years is reviewed. Themes covered include planning, design and technology; plot-holders and their livelihoods; institutions and organisations; support services; agronomic practices; and revitalisation. The availability of guidelines on most of these aspects is highlighted. Gaps in the knowledge of social, human and economic aspects of smallholder irrigation schemes are pointed out.
\end{abstract}

Keywords: smallholder, irrigation scheme, plot size, technology, livelihoods, farmer support, institutions, organisations, revitalisation, management

\section{Introduction}

The water deficit caused by low and erratic rainfall and high evaporative demand limits dryland crop production in most of South Africa. Irrigated agriculture presents an attractive alternative under these conditions. Irrigation refers to the artificial application of water to land for the purpose of enhancing plant production. It reduces or removes water deficit as a limiting factor in plant growth and makes it possible to grow crops where the climate is too dry for this purpose and to increase crop yields where plant-available soil water is a yield-limiting factor during parts or all of the growing season.

Irrigation water can be abstracted from the source and conveyed to the field by farmers individually or in a group as an irrigation scheme. Accordingly, an irrigation scheme can be defined as an agricultural project involving multiple holdings that depend on a shared distribution system for access to irrigation water and, in some cases, on a shared water storage or diversion facility. The term 'irrigation scheme' is also used more broadly to refer to a multitude of entities that correspond to this definition, when these entities share the same bulk conveyance system (Reinders et al., 2010).

In line with global irrigation development, which occurred mainly during the $20^{\text {th }}$ century (Turral et al., 2010), the area under irrigation in South Africa increased from $0.23 \times 10^{6}$ ha in 1909 (Scotney and Van der Merwe, 1995) to $1.2 \times 10^{6}$ ha in 1991 (Bruwer and Van Heerden, 1995), when 30\% of irrigated land was located in state irrigation schemes, $30 \%$ in schemes controlled by irrigation boards and $40 \%$ in private irrigation farms (Vaughan, 1997). The South African Government has rendered considerable support to irrigation development by

This paper was originally presented at the Water Research Commission 40-Year Celebration Conference, Kempton Park,

31 August - 1 September 2011.

* To whom all correspondence should be addressed.

욜 +27 12 382-5777; fax: +27 12 382-5869; e-mail: vanaverbekew@tut.ac.za providing subsidies to state irrigation schemes and irrigation board schemes. Several large state schemes were developed during the 1930s when South Africa was affected by severe drought and economic depression. State irrigation schemes were created to increase food production, insure agriculture against drought, establish new owner-operators in the farming sector, provide rural employment opportunities and develop new settlements (Backeberg and Groenewald, 1995a). Public funds were used to pay for the full capital development of state schemes and also for partial payment of their operating expenditure (Backeberg and Groenewald, 1995a), whilst irrigation board schemes received one third of the capital cost as a state subsidy (Vaughan, 1997).

During most of the $20^{\text {th }}$ century, South African social policies of racial segregation and separation benefitted whites (Beinart, 2001). Irrigation development was no exception and the lion's share of irrigation schemes was established for the settlement of White farmers (Bruwer and Van Heerden, 1995; Backeberg and Groenewald, 1995b). Moreover, irrigated holdings of White farmers, which ranged between 8 ha and 20 ha (Van Averbeke, 2008), were on average about 10 times larger than the 1.5 ha plots allocated to Black farmers (Denison and Manona, 2007b). The relatively small size of the irrigation plots allocated to Black farmers explains why in South Africa, the term 'smallholder irrigation scheme' is commonly used to refer to irrigation schemes on which the land is held by Black people (Machete et al., 2004). Accordingly, for the purpose of this article, smallholder irrigation scheme is defined as an irrigation scheme that was constructed specifically for occupation and use by Black farmers.

In South Africa, smallholder irrigation schemes are of secondary importance in terms of land area and farmer participation. In 2010, smallholder irrigation schemes covered 47667 ha, compared to the 1675822 ha of registered irrigation land in 2008, of which 1399221 ha was irrigated annually (Van der Stoep, 2011). The total population of 34158 plot-holders on smallholder irrigation schemes in 2010 was also relatively small compared to the 1.3 million Black homesteads that had 
access to land for cultivation (Vink and Van Rooyen, 2009). The importance of smallholder schemes arises primarily from their location in the former homelands, which continue to be poverty nodes (Vink and Van Rooyen, 2009). In these areas, irrigated farming has the potential to contribute significantly to food security and income of participating homesteads (Lipton et al., 1996; Bembridge, 2000), and to create employment, both directly and through forward and backward linkages to primary production (Backeberg et al., 1996). For this reason, the Water Research Commission (WRC) developed a keen interest in smallholder irrigation schemes, when from about 1990 onwards it broadened its agricultural water focus from water as a production factor to water as a livelihood resource, against a backdrop of political change in South Africa.

Indications are that the WRC made its first enquiry into smallholder irrigation schemes in South Africa in 1985, when it commissioned Jean-Claude Legoupil of CIRAD to participate in an irrigation workshop and advise on irrigation planning and development. Based on visits to 6 smallholder schemes located in different homelands, Legoupil (1985) concluded that: '(smallholder) irrigation, in spite of large-scale investment, is only marginally effective. Irrigation is failing to provide high yields and is beset by a whole range of problems: technical, management, training, agricultural policy, financing, etc. And yet in South Africa, the increase in food output can partially be achieved by a rise in the number of (smallholder) irrigation schemes, and the rehabilitation of abandoned ones. It is imperative, therefore, to develop a strategy for improvement of schemes, which encompasses not only the technical and economic aspects but also the participation and training of the farmers involved.'

In 1992, the WRC commissioned a second study aimed at providing a comprehensive overview of smallholder irrigation in South Africa. This investigation, conducted by De Lange (1994), indicated that there were probably about 150000 Black irrigators in the country, comprising 3 broad groups, namely:

- Independent irrigation farmers, who privately accessed and applied water to their farms

- Holders of allotments on irrigated community gardens

- Plot-holders on smallholder irrigation schemes

Du Plessis et al. (2002) added a fourth group comprising backyard or home-garden irrigators, who watered crops on parts of their residential sites. There was general agreement that, when combining the groups, Black irrigators farmed on about 100000 ha and that half of this irrigated area was located on smallholder irrigation schemes (Backeberg et al., 1996; Bembridge, 1997). This made smallholder irrigation schemes the most important in terms of irrigated area. IPTRID (2000) reported that in 1999, the combined area covered by the 2635 irrigated community gardens in KwaZulu-Natal amounted to 2055 ha. Extrapolating this figure to the 9 provinces would suggest that nationally, irrigated community gardens covered between 10000 ha and 20000 ha. By implication, the area farmed by independent irrigation farmers and home-garden irrigators would be of the order of 30000 ha to 40000 ha. IPTRID (2000) reported that, on average, irrigated community gardens in KwaZulu-Natal had a membership of 19 gardeners, and estimated that 51700 people were participating in these small irrigation projects. This lends support to Backeberg (2006), who indicated that the total population of Black irrigators in South Africa could be as high as 250000 .

One of the factors that probably focused the attention of the WRC on smallholder irrigation schemes, rather than on any of the other forms of irrigation practised by Black people, was that these schemes represented a substantial public investment, valued at R2 billion (R40 000 ha $^{-1}$ ) by Shah et al. (2002). Another was that irrigation schemes embodied sizeable concentrations of smallholders, which held the promise of good returns on resources invested in research. The need for research on smallholder irrigation schemes became even more imperative when the homeland parastatals, which were responsible for schemes that were constructed or refurbished during the homeland era, were closed down and irrigation-scheme management was transferred to farmers. Irrigation-management transfer was a global trend (Vermillion, 1997) but in the case of South African irrigation schemes, the process was rushed (Laker, 2004). Following its implementation, many schemes collapsed almost instantaneously, particularly the large schemes with complex designs and high management requirements (Bembridge, 2000). Guidance on how to revitalise these projects became a political priority.

For nearly 20 years, smallholder irrigation schemes have been one of the focal points of agricultural water research initiated, funded and managed by the WRC. Not all research on South African smallholder schemes has been conducted under the auspices of the WRC. Universities (Bembridge, 1984; Rossouw, 1989) and other organisations, such as the International Water Management Institute (Shah et al., 2002), also made important contributions; however, the body of knowledge produced by the WRC stands out for its coverage, depth and attention to practical application. In this article the knowledge that was generated by the WRC research is reviewed. For the purpose of the article, the database of South African smallholder irrigation schemes compiled in 2006 by Denison and Manona (2007b) was updated using primary and secondary information collected by the authors. Primary data were obtained by means of a comprehensive survey of smallholder irrigation schemes in Limpopo. Updates on schemes in other provinces were based on reports that were published after 2006.

\section{Overview of smallholder irrigation schemes in South Africa}

The available evidence indicates that in 2010 there were 302 smallholder irrigation schemes with a combined command area of 47667 ha in South Africa. The plot-holder population on these schemes totalled 34158 . Rivers were the principal source of water. A total of 46114 ha $(96.7 \%)$ obtained its water from rivers, either pumped directly, diverted by means of weirs, or through dam storage. Groundwater was used on 1405.5 ha $(3.0 \%)$, municipal water on 110 ha $(0.2 \%)$ and spring water on 37.6 ha (0.1\%). Water was pumped on 23111.8 ha (48.5\%), gravitated on 16497.2 ha (34.6\%) and on 8058.5 ha (16.9\%) gravity and pumping occurred in combination. On all existing schemes, the irrigation system was constructed after 1950. Smallholder irrigation scheme development in South Africa has a much longer history (Van, Averbeke, 2008), but in 2010, schemes that were constructed before 1950 no longer existed in their original form. One example was Taung in North-West Province, which dates back to 1939 (Bembridge, 1997), but the original canal irrigation system has been replaced with an overhead system.

In 1952, when the Commission for the Socio-Economic Development of the Bantu Areas within the Union of South Africa (1955) completed its data collection, it identified 122 smallholder irrigation schemes, which covered a total of 


\begin{tabular}{|c|c|c|c|c|c|c|c|c|c|}
\hline \multicolumn{10}{|c|}{$\begin{array}{c}\text { TABLE } 1 \\
\text { Operational status of South African smallholder irrigation schemes by province and irrigation system }\end{array}$} \\
\hline \multirow[t]{2}{*}{ Province } & \multicolumn{4}{|c|}{$\begin{array}{l}\begin{array}{c}\text { Number of operational schemes by irrigation } \\
\text { system }\end{array} \\
\end{array}$} & \multicolumn{4}{|c|}{$\begin{array}{l}\begin{array}{c}\text { Number of non-operational schemes by irrigation } \\
\text { system }\end{array} \\
\end{array}$} & \multirow[t]{2}{*}{ Total } \\
\hline & $\begin{array}{l}\text { Gravity-fed } \\
\text { surface }\end{array}$ & $\begin{array}{l}\text { Pumped } \\
\text { Surface }\end{array}$ & Overhead & Micro & $\begin{array}{c}\text { Gravity-fed } \\
\text { surface }\end{array}$ & $\begin{array}{l}\text { Pumped } \\
\text { Surface }\end{array}$ & Overhead & Micro & \\
\hline Limpopo & 49 & 9 & 30 & 13 & 12 & 5 & 41 & 11 & 170 \\
\hline Mpumalanga & 3 & 0 & 4 & 0 & 1 & 0 & 11 & 0 & 9 \\
\hline North West & 0 & 2 & 0 & 0 & 0 & 0 & 0 & 0 & 2 \\
\hline KwaZulu-Natal & 5 & 0 & 30 & 0 & 0 & 0 & 0 & 0 & 35 \\
\hline Free State & 0 & 1 & 0 & 0 & 1 & 0 & 0 & 0 & 2 \\
\hline Northern Cape & 0 & 2 & 0 & 0 & 0 & 1 & 0 & 0 & 3 \\
\hline Eastern Cape & 4 & 0 & 46 & 1 & 0 & 0 & 16 & 0 & 67 \\
\hline Western Cape & 6 & 0 & 1 & 0 & 0 & 0 & 1 & 0 & 8 \\
\hline Total & 67 & 14 & 111 & 14 & 14 & 6 & 59 & 11 & $296^{1}$ \\
\hline
\end{tabular}

${ }^{l}$ The operational status of six schemes, five in the Eastern Cape and one in KwaZulu-Natal, was not known, bringing the total to 302.

11406 ha. This irrigated area was held by 7538 plot-holders, each holding a plot with an average size of $1.513 \mathrm{ha}$. All of these were river-diversion schemes and it would appear that in most cases their water conveyance and distribution systems had no linings at that time (De Lange et al., 2000). After 1950, the state upgraded existing smallholder canal schemes by constructing permanent weirs or dams and by lining canals and furrows with concrete. Several new smallholder canal irrigation schemes were also built and all of these had concrete linings (Van Averbeke, 2008). At the time, the Commission for the Socio-Economic Development of the Bantu Areas within the Union of South Africa (1955) predicted that these lined canal schemes would have a 20 year to 40 year lifespan. However, some of them have now been in operation for more than 50 years, although most are presently in need of repairs (Van Averbeke, 2008). The construction of canal schemes came to an end around 1975. In the Vhembe District, for example, the last canal schemes that were built were Morgan and Klein Tshipise in 1974. Of the total command area covered by smallholder irrigation schemes in 2010, 12802 ha (26.9\%) was located on gravity-fed canal schemes. Invariably, surface irrigation was practised on such schemes, almost always by means of the short-furrow method (De Lange, 1994; Crosby et al., 2000; Van Averbeke, 2008). Surface irrigation occurred on an additional 3278 ha $(6.9 \%)$ located on pumped schemes, where shortfurrow or border-strip irrigation was practised.

Considerable smallholder irrigation development occurred between 1975 and 1985, particularly in the Eastern Cape (Van Averbeke et al., 1998). Overhead irrigation systems replaced canal irrigation in the design of these schemes, in line with the global trend of modernisation (Faurès et al., 2007). Some of the large smallholder schemes that were developed during this period in South Africa included Ncora, Keiskammahoek, Tyefu, Shiloh and Zanyokwe in the Eastern Cape. All of these projects were capital-intensive (Bembridge, 1987; Van Averbeke et al., 1998; Laker, 2000). For example, the cost of construction of the 473 ha pilot phase of the Tyefu scheme in 1976 amounted to R12 $000 \mathrm{ha}^{-1}$ (Bembridge, 1987), equivalent to R282 189 ha $^{-1}$ when adjusted to 2010 South African Rand values. In most cases, construction of these large schemes involved the building of dams and use was made of modern water-distribution and -application systems (Van Averbeke et al., 1998; Denison and Manona, 2007a). The mechanised farming system that prevailed on these schemes carried high operational and maintenance costs and required sophisticated management systems (Laker, 2004). All costs were expected to be carried by the projects but financial viability was never achieved. As a result, these projects remained dependent on state subsidies for continued operation (Van Averbeke et al., 1998; Laker 2004).

In 2010, various forms of overhead irrigation were found on the largest part of the existing command area of smallholder irrigation schemes. A total of 27758 ha (58.2\%) was involved, all on schemes that were built after 1975 or on schemes where the canal systems were replaced with overhead systems. The extent of micro-irrigation systems on smallholder schemes was limited to 3830 ha, which represented $8 \%$ of the total command area.

Not all 302 smallholder irrigation schemes were operational in 2010 and not all operational schemes were fully operational but the data available on provinces other than Limpopo Province did not allow for estimates of the extent to which operational schemes were functioning. Table 1 shows the operational status of the schemes by province in relation to irrigation method.

In 2010, 206 schemes were operational and 90 were not. The status of one gravity-fed canal scheme in KwaZuluNatal and 5 overhead irrigation schemes in the Eastern Cape could not be established. Significant was that the likelihood of schemes to be operational was $81 \%$ for gravity-fed canal schemes, $70 \%$ for pumped surface irrigation schemes, $65 \%$ for overhead irrigation schemes and $56 \%$ for micro-irrigation schemes. Among the primary constraints identified by extension staff on 164 of the 302 smallholder schemes, poor management topped the list (50\% of the cases); followed by infrastructural problems (15\%); water inadequacies (13\%); conflict $(12 \%)$; and theft (7\%). This suggests that human (capacity) and social (institutional) resource problems were at the heart of the below-expected performance of smallholder irrigation schemes in South Africa identified by nearly all assessments that were made (Bembridge, 1997; Bembridge, 2000; Kamara et al., 2001; Shah et al., 2002; Machete et al., 2004; iSeneke Developments, 2004; Tlou et al., 2006; Speelman et al., 2008; Yokwe, 2009; Mnkeni et al., 2010).

Figure 1 shows the frequency distribution of the command area of smallholder irrigation schemes. The majority of schemes $(65 \%)$ had a command area that did not exceed 100 ha and all but 18 schemes had a command area that did not exceed 500 ha. Only 6 schemes were larger than 1000 ha. These included Majeje (1 $169 \mathrm{ha})$ and Middle Letaba (1 $730 \mathrm{ha})$ in Limpopo Province, both not operational; Ncora (2 490 ha) and Qamata (2 635 ha) in the Eastern Cape and Makhatini 


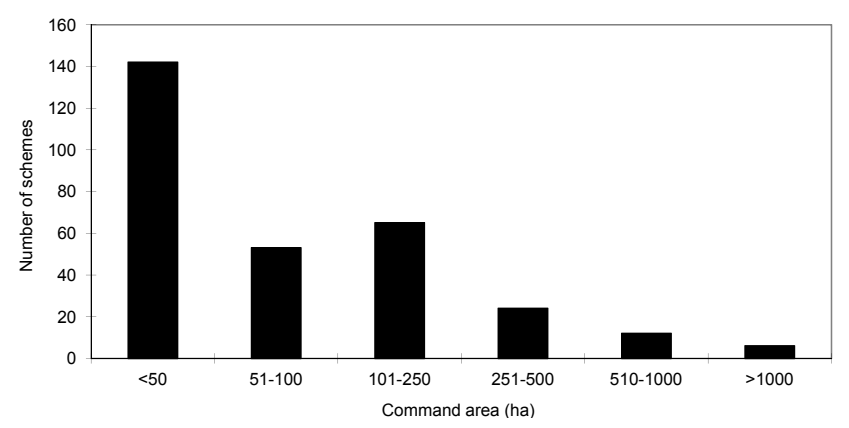

Figure 1

Frequency distribution of the command area of smallholder irrigation schemes in South Africa

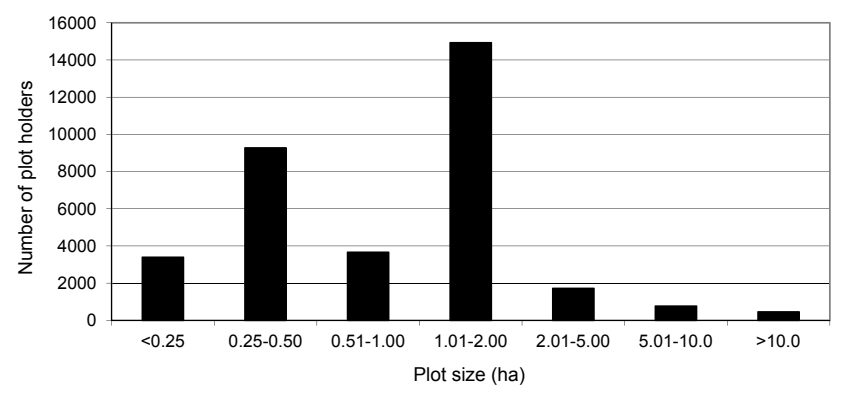

Figure 2

Frequency distribution of the size of plots among plot-holders on South African smallholder irrigation schemes

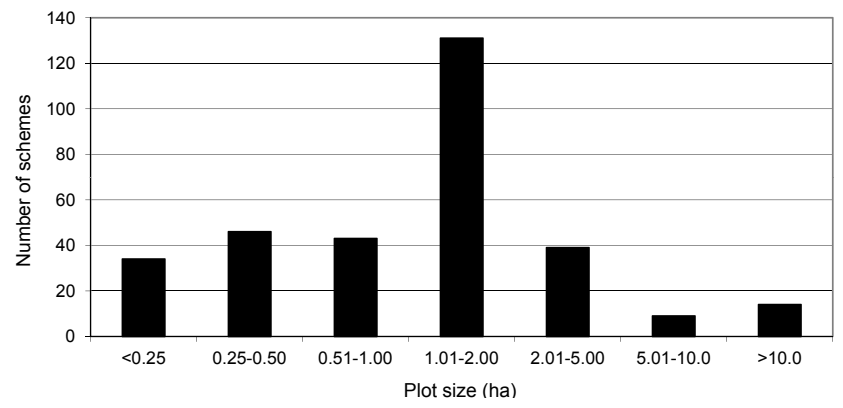

Figure 3

Frequency distribution of average plot size among South African smallholder irrigation schemes

(2 620 ha) in KwaZulu-Natal, all operating at a fraction of their capacity; and Taung ( 3500 ha) in North-West Province, the only large project that was operating reasonably well. Figure 1 shows the dominance of small schemes.

Figure 2 shows the frequency distribution of plot size among plot-holders on smallholder irrigation schemes. One of the peaks in Fig. 2 represented plots not exceeding 0.5 ha. These could be regarded as food plots, because farming on these small plots was shown to serve primarily as a source of food for plot-holder homesteads (Vaughan, 1997; Van Averbeke et al., 1998). The other peak represented plots that were between 1 ha and 2 ha in size.

Figure 3 shows the average plot size among irrigation schemes. Of the 302 smallholder schemes, 131 (43\%) had plots that were between 1 ha and 2 ha in size. The use of plots in this size category has been shown to vary among schemes and within schemes, with some allotments being used mainly to produce food for own consumption and others primarily for commercial purposes.
Among schemes, the position of the scheme in relation to markets appeared to be the key factor that determined the balance between subsistence and commercial production on 1 ha to 2 ha plots (Bembridge and Sebotja, 1992; Kamara et al., 2001; Machete et al., 2004). In some instances, the position of the scheme in relation to markets was purely a spatial factor, with distance to the nearest urban centre and state of the roads linking the scheme to that centre as the key factors, because marketing of produce was done mostly by street traders and 'bakkie' (small van) traders (Van Averbeke, 2008; Magingxa et al., 2009). Schemes located next to a major road, which enabled farmers to trade directly with customers, was a variation of this spatial factor (Laker, 2000). In other instances, the position of the scheme in relation to markets was a function of institutional arrangements. This applied to projects where agencies provided a marketing service, as in the case of sugar cane (Bembridge, 2000), and also to projects where farmers marketed their produce as an association instead of individually (Magingxa et al., 2009).

Within schemes, the purpose of farming on plots of 1 ha to 2 ha was shown to be dependent on the role irrigation played in the livelihood of individual plot-holder homesteads (Van Averbeke and Mohamed, 2006). Stage of life of plot-holders, their sources of income other than farming, and the importance of farming in their portfolio of livelihood activities, affected why and how plot-holders farmed at the Dzindi Canal Scheme (Van Averbeke and Mohamed, 2006). Also significant was that the farming objective and farming style of several plot-holders on this Scheme changed over a period of 2 years. The observed changes were as a response to developments that affected the structure of their livelihoods. Aliber and Hart (2009) alluded to a similar association, when they pointed out that changes in livelihood structure of rural Black homesteads in South Africa appeared to influence whether they engaged in farming or not. Consequently, variability in production and productivity among plot-holders on smallholder irrigation schemes with 1 ha to 2 ha plots should be considered as characteristic. By implication, interventions aimed at increasing productivity of farm enterprises on these schemes will be relevant to a fraction of the plot-holder population only.

Bembridge (2000) indicated that commercial orientation of irrigated agriculture on smallholder schemes was mostly restricted to plots larger than 2 ha. In 2010, there were only 2925 plots larger than 2 ha on smallholder schemes. In many cases, but not all, farming on these large plots involved the production of specific crops, which was being supported by a range of services, including access to production loans, delivery of inputs, specialised production advice and reliable markets. Examples of such arrangements were the production of sugar cane on schemes in Mpumalanga, barley at Taung and raisin grapes at Eksteenkuil in the Northern Cape.

\section{What has been learnt?}

Since 1992, when the WRC initiated its first research project on smallholder irrigation schemes in South Africa (Crosby et al., 2000), a total of 16 reports have been published on this topic. Roughly categorised, these publications consist of 2 reports that set the scene (De Lange, 1994; Laker, 2004), 5 assessments (Van Averbeke et al., 1998; Du Plessis and Van der Stoep, 2001; Machete et al., 2004; iSeneke Developments, 2004; Tlou et al., 2006), 7 guideline documents (Bembridge, 2000; Crosby et al., 2000; De Lange et al., 2000; Du Plessis et al., 2002; Denison and Manona, 2007a; b; Umhlaba, 2010a), and 2 studies aimed 
at developing best management practices for use at scheme and farm level (Van Averbeke, 2008; Mnkeni et al., 2010). Most of these reports contain case-study results. Work is continuing and is focused on some of the remaining knowledge gaps discussed later on.

As was pointed out earlier, most researchers who studied South African smallholder irrigation schemes concluded that the performance of the majority of these projects was well below potential. Typically, poor performance was associated with a range of factors, including poor maintenance of infrastructure and equipment; high energy costs where pumping was involved; lack of institutional support in terms of credit; marketing and draught power; lack of extension and farmer training; conflict; and weak local organisation (Bembridge, 2000). Yet, 60 years ago, the Commission for the SocioEconomic Development of the Bantu Areas within the Union of South Africa (1955) identified irrigated farming on plots of 1 to 2 ha as the most successful and financially viable of all Black farming enterprises at that time. What happened? Two related historical trends provide part of the explanation.

The first trend has been the steady decline in Black homestead agriculture, particularly cultivation. In 1950, most Black rural homesteads were still farming. The majority did not meet their subsistence requirements and few produced a surplus, but income generated from other livelihood activities, mainly earned by male migrants working in mines and cities, was used to maintain the rural homestead and its agricultural activities (Houghton, 1952; Lahiff, 2000, Hebinck and Van Averbeke, 2007; Van Averbeke, 2008). Since 1950, Black rural homesteads have increasingly discontinued the cultivation of their arable allotments. Recent case studies in the Ciskei region of the Eastern Cape showed that only about $10 \%$ of the fields were ploughed annually (Hebinck and Monde, 2007; De Wet, 2011). At present, crop production occurs mostly in home gardens, explaining why farming now only serves as an additional source of food for the large majority of Black households (Vink and Van Rooyen, 2009; Aliber and Hart, 2009). The second trend has been the rise in the competitiveness and sophistication of commercial agriculture and the food-supply system in South Africa. Shored up by state support during much of the $20^{\text {th }}$ century, commercial farming successfully met the challenge imposed by the liberalisation of agriculture during the last decade of that century (Vink and Kirsten, 2003; Ortmann and Machete, 2003). The result has been the establishment of a national food-production and -distribution system that reliably provides relatively cheap food of good quality almost anywhere in the country, making it very difficult for smallholders to compete (Laker, 2004; Ramabulana, 2011). The disappointing performance of smallholder irrigation schemes needs to be understood in this context, even though much can be done to improve their performance. Research under the auspices of the WRC has identified various ways to bring this about. The findings will now be discussed thematically even though problemsolving in agriculture and particularly irrigated agriculture requires a holistic approach that considers and integrates the full range of factors that apply to particular circumstances (Bembridge, 2000).

\section{Planning, design and technology}

Crosby et al. (2000) developed a comprehensive manual for the planning and design of smallholder irrigation projects. The manual provides guidelines for pre-feasibility and feasibility studies, participatory irrigation planning, managing

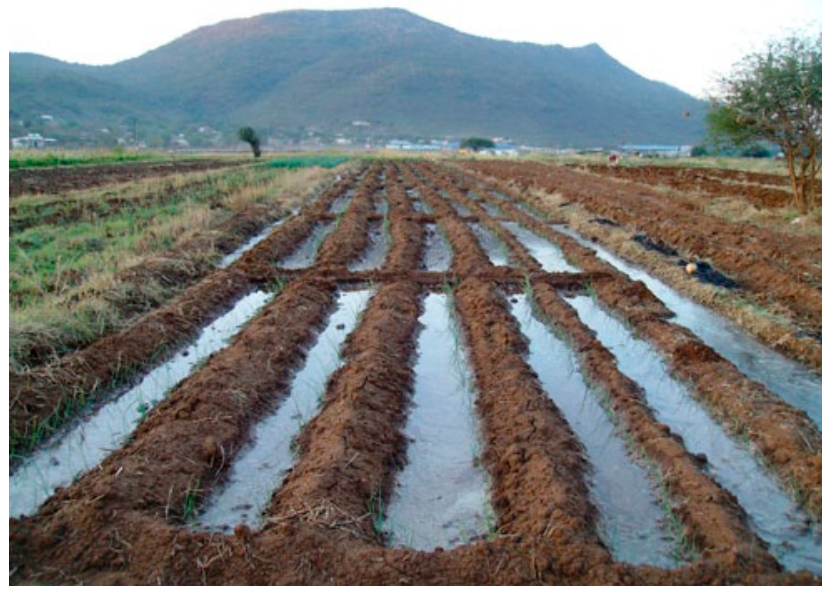

Figure 4

Short furrow irrigation at the Steelpoort Canal Irrigation Scheme in Limpopo Province

crop-water requirements, water supply and management. It also contains specific guidelines for pressurised systems and short-furrow irrigation. Crosby et al. (2000) reported that short-furrow irrigation, shown in Fig. 4, could match and even exceed the irrigation efficiency of other systems, when used correctly.

Relative to gravity-fed canal schemes where surface irrigation was practised, the main advantages of pressurised systems were lower establishment costs per unit area and reduced labour in irrigation for farming families, enabling them to irrigate larger plots. Important disadvantages were shorter lifespans of the systems, higher operating costs and greater maintenance requirements. Du Plessis and Van der Stoep (2001) paid specific attention to the application of micro-irrigation in smallholder agriculture, which included micro-sprayer and drip systems. Their findings indicated that successful micro-irrigation was not out of the reach of smallholders but highly dependent on a range of requirements being met and support services being available. This made micro-irrigation systems a risky option. Their conclusion is supported by the data in Table 1, which showed that the proportion of non-operational micro-irrigation schemes was higher than that of schemes that used other technology. Du Plessis et al. (2002) captured their experiences with the implementation and use of micro-irrigation in smallholder settings in a comprehensive manual for use by planners, designers and support staff.

\section{Plot-holders and their livelihoods}

Plot-holders and their livelihoods are at the centre of farming on smallholder irrigation schemes but they have received surprisingly little attention in some of the research that has been done by the WRC. These reports usually depicted plot-holders as old, poor, mostly female, uneducated people, incapable of dealing with the sophisticated management requirements of irrigated farming and victims of their dependency on the state and its agencies (Van Averbeke et al., 1998; Bembridge, 2000; iSeneke Developments, 2004; Mnkeni et al., 2010). The livelihoods study carried out by Mohamed (2006) on the Dzindi Canal Scheme, and especially his descriptions of a sample of smallholder homesteads at that scheme, demonstrated the agency of farmers and illustrated how irrigated farming featured in their livelihoods over time. 


\begin{tabular}{|c|c|c|c|c|c|}
\hline \multicolumn{6}{|c|}{$\begin{array}{c}\text { TABLE } 2 \\
\text { Gross farm income and total income of plot-holder homesteads at selected South African smallholder } \\
\text { irrigation schemes adjusted to } 2010 \text { rand values }\end{array}$} \\
\hline \multirow[t]{2}{*}{ Scheme name } & \multirow[t]{2}{*}{$\begin{array}{l}\text { Plot size range } \\
\text { (ha) }\end{array}$} & \multirow[t]{2}{*}{$\begin{array}{l}\text { Year of data } \\
\text { collection }\end{array}$} & $\begin{array}{l}\text { Total } \\
\text { homestead } \\
\text { income }\end{array}$ & $\begin{array}{l}\text { Gross farm } \\
\text { income }\end{array}$ & \multirow{2}{*}{$\begin{array}{c}\begin{array}{c}\text { Contribution } \\
\text { of gross farm } \\
\text { income to total } \\
\text { homestead } \\
\text { income (\%) }\end{array} \\
\end{array}$} \\
\hline & & & \multicolumn{2}{|c|}{ (2010 rand values) } & \\
\hline Tyefu food plots & $0.16-0.25$ & 1995 & 12024 & 452 & \begin{tabular}{|l|}
3.8 \\
\end{tabular} \\
\hline Zanyokwe food plots & 0.20 & 1995 & 8481 & 1074 & 12.7 \\
\hline Keiskammahoek (Upper Gxulu) & 0.25 & 1995 & 14937 & 420 & 2.8 \\
\hline Shiloh food plots & 0.25 & 1995 & 11496 & 741 & 6.4 \\
\hline Hertzog Agricultural Coop. & 1.00 & 1995 & 25623 & 7017 & 27.4 \\
\hline Qamata & 1.28 & 1997 & 17045 & 3443 & 20.2 \\
\hline Dzindi & 1.28 & 2003 & 36110 & 7136 & 19.8 \\
\hline Horsehoe & 2.00 & 1995 & 22540 & 12822 & 56.9 \\
\hline Elandskraal & $0.7-5.0$ & 2000 & 28499 & 11867 & 41.0 \\
\hline Zanyokwe & $2.0-11.0$ & 2007 & 21501 & 17454 & 81.2 \\
\hline
\end{tabular}

Research conducted outside the ambits of the WRC sheds some light on the politics of irrigation at Tyefu in the Eastern Cape (Holbrook, 1998) and on the precarious social position of settler farmers at Keiskammahoek amidst a community that viewed them as intruders (Holbrook, 1996).

Information on the incomes of plot-holder homesteads and on the contributions of irrigated farming to these incomes is also limited. Table 2 summarises the findings of studies by Bembridge (1984), Van Averbeke et al. (1998) and Mnkeni et al. (2010) on schemes in the Eastern Cape and Machete et al. (2004) and Van Averbeke (2008) on schemes in Limpopo Province. All monetary values shown in Table 2 were adjusted to 2010 rand values using the Consumer Price Index published by Statistics SA (2011). Table 2 shows that plot-holder homesteads did not derive income only from farming, indicating that their livelihood strategies included other livelihood activities or sources of income. As could be expected, income from farming was positively associated with plot size. Of greater significance for rural economic development policy was that both total homestead income and the proportion of homestead income that was derived from irrigated farming tended to increase as plot size increased. The data in Table 2 also clearly indicate that irrigated farming on a plot of 1.5 morgen (1.28 ha) no longer provided homesteads with adequate incomes, as had been the case in 1952 (Commission for the Socio-Economic Development of the Bantu Areas within the Union of South Africa, 1955).

Virtually no information has been generated on livelihoods that are linked to farming on smallholder schemes, but evidence presented by Van Averbeke (2008) suggests that in some cases the number of linked livelihoods could be substantial. The Limpopo Department of Agriculture referred to livelihood linkages and other social and economic benefits as the sphere of influence of smallholder irrigation schemes during the early phase of its RESIS programme that was aimed at revitalising these schemes (Van Averbeke, 2008) but this notion has received little research attention.

\section{Institutions and organisations}

Farmers on irrigation schemes are dependent on each other, because they share the water distribution system. This interdependence requires a willingness on the side of farmers to work collectively in order to achieve their individual objectives.
The domains in which farmers on irrigation schemes have to collaborate include the routine maintenance of the water distribution system (Letsoalo and Van Averbeke, 2006a), payment for energy where pumping is involved (Machete et al., 2004) and payment for water where this has been instituted (Backeberg, 2005). On many schemes, particularly canal schemes, collaborative arrangements governing the distribution of water to the various hydraulic units and individual plots is essential to ensure that all farmers get their fair share (Letsoalo and Van Averbeke, 2005b; Van Averbeke, 2008). In addition, farming on smallholder schemes can benefit from a collective approach to market access, both input and output (Letsoalo and Van Averbeke 2005b; Van Averbeke, 2008). Rules to govern collaboration (institutions) and structures to enforce these rules (organisations) are necessary for effective and sustainable functioning of collective action. Indications are that on their own, irrigator communities and their volunteer leadership structures, usually in the form of elected scheme committees, find it difficult to enforce rules. Farmers pursuing individual goals (rational individual behaviour) instead of collective goals (rational collective behaviour) challenge institutions and erode organisations of irrigator communities (Letsoalo and Van Averbeke, 2006a; Orne-Gliemann, 2008).

Institutional and organisational decline has its most profound impact on routine maintenance of the water distribution system, which includes cleaning and minor repairs (Letsoalo and Van Averbeke, 2006a). Inadequate routine maintenance reduces water delivery and shortens the life-span of the water distribution system, posing a threat to the sustainability of irrigated farming. Shah et al. (2002) identified inadequate routine maintenance as one of the important factors that contributed to the 'downward ratchet' that characterised smallholder irrigation schemes in South Africa. De Lange et al. (2000), paid considerable attention to the building of social capital among irrigator communities in their guidelines for trainers and development facilitators, but evidence suggests that capacity on its own might not be enough (Van Averbeke, 2008). Ways to support the institutions and organisations of smallholder irrigation scheme communities need to be investigated more thoroughly.

Assessments of smallholder irrigation schemes invariably identified the institution of land tenure to be an important factor for 3 main reasons. Firstly, tenure restrictions prevented the development of a land-exchange market among farmers (Van Averbeke et al., 1998; Bembridge, 2000). Poorly functioning 
land-exchange markets prevented plot-holders to adapt the size of their farm enterprises to their capacity to produce, resulting in the coexistence of demand for land and land surplus (Van Averbeke, 2008). Secondly, several studies indicated that men were the holder of plots, whilst women were doing the farming (Machete et al., 2004; Tlou et al., 2006). Thirdly, the tenure system that applied on nearly all schemes precluded farmers from using their holding as collateral to access loans from registered financial service providers (Crosby et al., 2000; Machete et al., 2004; Tlou et al., 2006).

The research by Tlou et al. (2006) was commissioned specifically to provide clarity and recommendations on land tenure in smallholder irrigation schemes. Their analysis, which used system on system effects, identified tenure as the system that had the greatest overall impact on other systems relevant to irrigation farming, but apart from the link between tenure and access to finance, they provided little concrete evidence in support of this conclusion. From a legal perspective, tenure on irrigation schemes is ambiguous to say the least, because much of the legislation that applied when plots were first allocated has since been revoked (Manona et al., 2010). Yet, on many schemes plot-holders tended to feel secure about crucial tenure rights, such as who the plot belonged to. They felt less secure about other rights, such as the right to rent out land, mainly because in the past renting out land was forbidden by the conditions of occupation (Van Averbeke, 2008). Conversely, plot-holders also felt insecure about renting in land, because there was no legal protection against owners claiming back their plots before the lease arrangement had expired (Vaughan, 1997; Van Averbeke, 2008). Manona et al. (2010) argued that the development of scheme-based land-administration systems could remove most of the uncertainties surrounding land rights and lease contracts.

Tenure was shown to be a critical factor where imposition of the irrigation scheme tenure system was subject to conditions (The Commission of Enquiry, 1996). This occurred at Ncora in the Eastern Cape, where traditional tenure rights over relatively large dryland plots were given up in return for smaller-sized irrigation plots and specified benefits. These benefits included subsidised land preparation, farm inputs and an annual dividend. The issue of these benefits was dependent on profits generated by the estate farm, which was given the right to use the bulk of the land that had become available by the arrangement. When the estate farm was no longer in a position to pay for the benefits, plot-holders demanded their old land rights back. The ensuing conflict over land rights was a major factor in the virtual collapse of Ncora. A similar scenario could well develop on the smallholder irrigation schemes in Limpopo Province that have been revitalised by the RECHARGE model of the RESIS (Revitalisation of Smallholder Irrigation Schemes) Programme. For example, at Tshiombo Block 1A, the plots of 86 individual plot-holders, which were irrigated using the gravity-fed short-furrow method, were consolidated in a single 100 ha unit under floppy irrigation (Fig. 5), to be farmed by a White farmer, referred to as the strategic partner, in return for dividends. The plot-holders were reduced to land owners who observed farming. Dividends paid out to plot-holders of Tshiombo Block 1A have been substantial, matching the net operating income of the most productive quintile of smallholders on canal scheme plots of similar size recorded by Van Averbeke and Mohamed (2006). However, the annual potato-maize rotation that generated the profits at Tshiombo was unlikely to be sustainable, because of progressively increasing pest and disease loads. Moreover, the duration

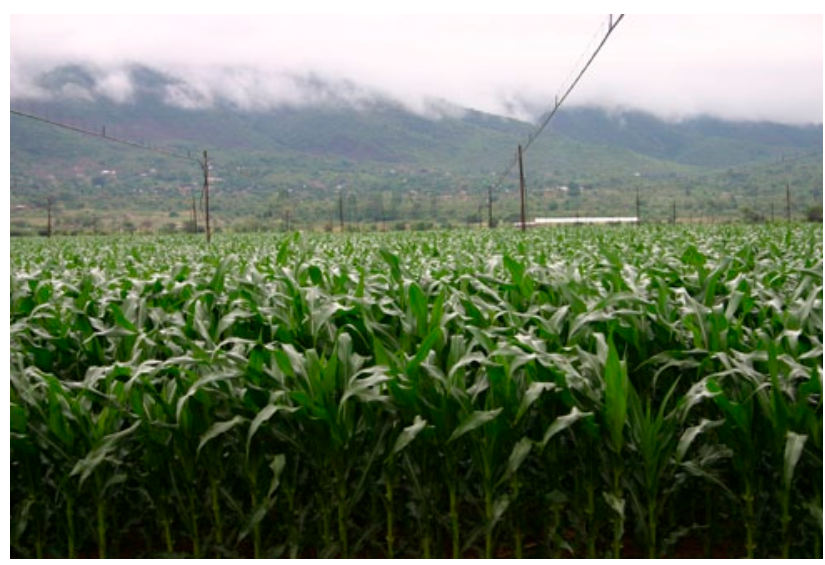

Figure 5

At Block $1 A$ of the Tshiombo Canal Scheme 80 plots have been consolidated into a single land holding under floppy irrigation that is farmed by a strategic partner using a an annual maizepotato rotation

of the contractual agreement between the strategic partner, the Limpopo Department of Agriculture and the plot-holders was only for a period of 3 years. If and when management of Tshiombo Block 1A will be transferred back to plot-holders, questions around tenure will arise, because the original layout of the scheme has been obliterated by the removal of the concrete furrows that acted as plot boundaries.

Water user associations (WUAs) are provided for in the National Water Act 36 of 1998 and are defined as water management associations with restricted objectives (Backeberg, 2003). There has been the expectation that WUAs would assist smallholder irrigation scheme development (Backeberg, 2005), but this has not materialised yet. On the contrary, their impact appears to be very limited. For example, of 45 smallholder irrigation schemes sampled in Limpopo Province, 28 claimed to be part of a WUA but only one effectively participated in its activities. Payment for water on these 28 schemes, which was linked to WUA membership, was taken care of by the Department of Agriculture on behalf of farmers. The results of several studies have indicated that smallholders would face financial difficulties if they had to pay for the water themselves (Van Averbeke et al., 1998; Speelman et al., 2008; Yokwe, 2009; Speelman et al., 2011).

\section{Support services}

Weak support services are a recurrent theme in most smallholder irrigation scheme assessments (Bembridge, 2000; Machete et al., 2004; iSeneke Developments, 2004; Tlou et al., 2006; Mnkeni et al., 2010). There is general agreement that human and social capacity development among smallholder irrigators is a pre-condition for turning the current 'downward ratchet' trajectory of schemes into an upward one (Shah et al., 2002). Training of farmers and their collectives is needed in the domains of farm and scheme management. The provision of support with the development of reliable networks for the marketing of produce beyond the local environs is also critical (Magingxa et al., 2009). Provision of these support services to smallholders became the principal mandate of public extension some 15 years ago, following the withdrawal of provincial departments of agriculture from active involvement in scheme management. Legoupil (1985) emphasised that irrigated farming could only become successful when farmers adopted new 
farming systems that were more intensive and productive than those they employed when they cultivated dryland plots. He pointed out that when irrigated farming was limited to the mere application of water to crops to avoid water stress, without simultaneously attending to issues of plant nutrition, cultivar choice, plant population and plant protection, it would never be sustainable. Backeberg $(2003 ; 2005)$ reiterated this argument in his assessments of the future of smallholder irrigation in the context of the new South African Water Policy and farmers' willingness and ability to pay for water. In the green revolution, which is now credited for creating the platform for the rapid economic development of several Asian countries (Turral et al., 2010), irrigation was but one of the 3 main ingredients, choice of crop and fertilisers being the others. The paternalistic approach to farmer training and service provision that was used when White farmers were settled on irrigation schemes (Backeberg and Groenewald, 1995b) and on smallholder schemes during the 1950s (Commission for the Socio-Economic Development of the Bantu Areas within the Union of South Africa, 1955; Van Averbeke, 2008) has been seriously criticised (Machete et al., 2004; Tlou et al., 2006) and with reason, but services were provided and gradually farmers developed the necessary capacity to assume responsibility over managing their farms and schemes and to become less dependent on public extension and more on each other for the acquisition of new knowledge and the exploitation of marketing opportunities (Backeberg, 2005). On most smallholder irrigation schemes, farmers have not reached the necessary level of competency and confidence to optimally exploit their farms. The need for support services is universal, even though it varies among schemes. To date, tertiary education responsible for the training of extension staff and managers, agricultural research institutions responsible for innovation in smallholder irrigation, and public extension responsible to guide and support farmer development, have all fallen short of fulfilling their mandates.

\section{Agronomic practices}

The low yields realised by smallholders have been concrete evidence of poor farmer performance on smallholder irrigation schemes (Crosby et al., 2000). Maize grain yields averaging less than $3 \mathrm{t} \cdot \mathrm{ha}^{-1}$ have been recorded on several schemes (Van Averbeke et al., 1998; Machete et al., 2004; Van Averbeke, 2008; Mnkeni et al., 2010). Machete et al. (2004) linked low crop yields to limited knowledge and lack of skills in crop production among farmers. Denison and Manona (2007a) concurred and recommended that crop production approaches, including farmer training, be considered as an essential component of smallholder irrigation scheme revitalisation strategies. Machete et al. (2004) and Mnkeni et al. (2010) identified basic management practices, such as weed, water, fertiliser and plant population management, late planting, and choice of cultivars, all of which were within the farmers' abilities to control, as the main agronomic factors limiting productivity.

At Zanyokwe in the Eastern Cape, yield gap analysis of grain maize and butternut indicated that large gaps existed between yields achieved by farmers and those achieved with good management in researcher-managed, on-farm trials (Fanadzo et al., 2010). The average yield of $2.4 \mathrm{t}$ maize grain ha $^{-1}$ and $6 \mathrm{t}$ butternut $\cdot \mathrm{ha}^{-1}$ was less than $25 \%$ of the maximum economic yield achieved at Zanyokwe in on-farm experiments managed by researchers (Fanadzo et al., 2010). Even though experimental plots are easier to manage than field-scale plantings, these findings suggested that inadequate farm management rather than infrastructural constraints was the principal factor that limited crop productivity at Zanyokwe. As a result of this finding Mnkeni et al. (2010) came to the conclusion that investment in the building of capacity and competence among farmers could improve scheme performance. Research aimed at developing practices to alleviate agronomic factors that limited crop yield showed that planting time and nitrogen application rate had a major effect on grain yield at Zanyokwe (Mnkeni et al., 2010). High yields were obtained when maize was planted early and fertilised with $250 \mathrm{~kg} \mathrm{~N} \cdot \mathrm{ha}^{-1}$. It should be noted that hybrid maize yielded $50 \%$ to $65 \%$ more than the open pollinated varieties commonly grown by farmers.

In different parts of the country, the production of irrigated maize for the purpose of selling green cobs has been identified as a lucrative smallholder enterprise (Khuvutlu and Laker, 1993; Van Averbeke, 2008; Mnkeni et al., 2010). At Dzindi in Limpopo Province, Van Averbeke (2008) reported a highly significant positive correlation $(r=0.72)$ between the gross margin of maize production and the proportion of cobs that were sold as green cobs. He explained this relationship by pointing out that the monetary value of a green cob was about 5 times higher than a cob harvested for grain. He reported that at most, farmers at Dzindi sold $25 \%$ of their maize as green cobs. For street traders, who were their main clients, most cobs produced by farmers were too small. In researcher-managed on-farm experiments, it was demonstrated that the proportion of cobs that were large enough for street traders could be raised to $75 \%$ by planting suitable cultivars, optimising planting density and applying fertilisers at recommended rates (Van Averbeke, 2008). Farmers who adopted recommended cultivars in their maize production system sold $40 \%$ of their cobs to street traders, without any other changes to their system. The substantial positive impact of this single modification illustrates the potential to improve smallholder production and productivity through adaptive research. At Zanyokwe, Mnkeni et al. (2010) showed that by transplanting maize seedlings with the intention of producing and harvesting green cobs, the duration of growth in the field was shortened and the gaps in the canopy were reduced, compared to direct seeding. Transplanted maize could be grown at lower nitrogen rates to achieve similar yield potentials as direct-seeded maize (Fanadzo et al., 2009). The combination of reduced post-emergence herbicide dosages of atrazine and use of narrow-row plant spacing was shown to be an effective weed-management strategy for maize at Zanyokwe, where pre-plant weed control was identified as the most important factor affecting butternut yield (Fanadzo et al., 2010).

\section{Revitalisation}

Lankford and Gillingham (2001) described irrigation schemes as highly case-specific, potentially complex, dynamic, sociobiophysical entities. The case-specificity of smallholder irrigation schemes arises from the multitude of factors that affect them such as objective, natural resource base, technology, scheme and plot size, farmer profile and marketing opportunities (Bembridge, 2000; Perret and Touchain, 2002; Lankford, 2004; Bolding, 2007). Diversity among schemes calls for different kinds of interventions to respond to varying farmers' needs, resources and agricultural contexts. In a detailed review of rehabilitation and revitalisation programmes in South Africa, Denison and Manona (2007b), identified a lack of appreciation of differing needs and contexts and noted that the focus had been largely on the upgrading of technology, 


\begin{tabular}{|c|c|c|c|}
\hline \multicolumn{4}{|c|}{$\begin{array}{c}\text { TABLE } 3 \\
\text { Typology of South African smallholder irrigation schemes (adapted from Denison and Manona, 2007b) }\end{array}$} \\
\hline Scheme type & $\begin{array}{l}\text { Typical plot } \\
\text { size }\end{array}$ & $\begin{array}{l}\text { Typical irrigation } \\
\text { system }\end{array}$ & Purpose of farming and farming system \\
\hline Food plot & $<0.5$ ha & $\begin{array}{l}\text { Canal irrigation or } \\
\text { moveable sprinklers }\end{array}$ & $\begin{array}{l}\text { Mainly for own consumption with some local marketing. } \\
\text { Low external input approaches to production. }\end{array}$ \\
\hline Peasant & 1 ha to 2 ha & $\begin{array}{l}\text { Preferably canal } \\
\text { irrigation }\end{array}$ & $\begin{array}{l}\text { Diverse purposes in line with diversified livelihoods of plot-holders } \\
\text { and diverse approaches to production reflecting risk appetite. Local } \\
\text { (urban) markets dominate, but with assistance distant city markets } \\
\text { could be accessed. }\end{array}$ \\
\hline $\begin{array}{l}\text { Commercial } \\
\text { farmer }\end{array}$ & $>2$ ha & $\begin{array}{l}\text { Relatively simple } \\
\text { overhead or } \\
\text { micro-irrigation }\end{array}$ & $\begin{array}{l}\text { Full-time, commercial farming that includes engagement with distant } \\
\text { markets. Highly productive farming systems are necessary and access } \\
\text { to finance could be a requirement. }\end{array}$ \\
\hline Equity-labourer & $\begin{array}{l}\text { Consolidated } \\
\text { landholding }\end{array}$ & $\begin{array}{l}\text { Complex overhead or } \\
\text { micro-irrigation }\end{array}$ & $\begin{array}{l}\text { Commercial farming with strategic partner who manages the enter- } \\
\text { prise, whilst plot-holders are farm workers, who also receive a share in } \\
\text { the profits in return for providing the land. }\end{array}$ \\
\hline
\end{tabular}

contributing to repeated failure of state-funded interventions to achieve farmer development objectives. Using 3 interdependent factors, Denison and Manona (2007a; b) identified 4 types of South African smallholder schemes. Factors used were profitability of farm enterprises, irrigation system and plot size. These 4 types of schemes were food-plot schemes, peasant schemes, business-farmer schemes and equity-labourer schemes. A summary of their important characteristics is presented in Table 3. Even though the typology of irrigation schemes referred to in Table 3 is only indicative, it provides insight into the current situation and can be used to identify revitalisation choices and their likely impact on irrigation scheme communities.

Most revitalisation efforts have seen little return, or worse, have resulted in perverse development outcomes. Denison and Manona (2007b) reported that rehabilitation of pumpedsprinkler schemes and conversion of canal schemes to pumped overhead or drip systems, forced a high-yield commercialisation agenda and an unavoidable drive for land consolidation. This resulted in the elimination of two of the most vulnerable groups on schemes, namely food-plot producers and peasants, because they could not survive financially under these higher cost and more risky operating and financial conditions. The effect of complex irrigation technology was assessed in an analysis of 10 feasibility studies on smallholder schemes conducted in 2004, where it was seen that enterprise models were forced to shift to higher-value crops to justify the revitalisation investment on economic grounds and to meet water, electricity and management costs (Denison and Manona, 2007b). Typical medium-value crops such as mixed vegetables at realistic yield levels showed gross margins of R12 $000 \mathrm{ha}^{-1}$ to R16 $000 \mathrm{ha}^{-1}$, and provided net cash returns to farmers of only R8 $000 \mathrm{ha}^{-1} \cdot \mathrm{a}^{-1}$ to R10 $000 \mathrm{ha}^{-1} \cdot \mathrm{a}^{-1}$ in 2004 prices. These returns were insufficient to justify state investment to rehabilitate the schemes. Furthermore, they found that the net returns for individual farmers were unacceptably low against the production investment costs and risks and did not generate interest in farming, because individuals generally held relatively small plots.

Horticulture is presented by some as an answer to the challenge of achieving high returns from small plot sizes. International evidence shows that 'self-supervising' qualities of family labour can be successfully deployed for high-value crops on small plots (Feder, 1985; Collins, 1995). Conradie et al. (1996) demonstrated the potential profitability of smallholder horticulture in South Africa but to succeed, small-scale producers required the same access to supply services, processing facilities and product markets as large-scale farmers. Experience shows that this has rarely been the case in South Africa and the increasingly sophisticated value chains that link large-scale producers to the 4 large supermarket chains in South Africa, which retailed about $60 \%$ of the food in 2008 , pose a major challenge to smallholders (Ramabulana, 2011).

The reality of high costs on technically complex schemes, coupled with an inability for engagement with higher-value crop mixes and value chains, has led to a clear pattern of land consolidation into larger farms, with farming activities being carried out by fewer, more skilled and resourced individuals. This pattern is not limited to smallholder agriculture. Fewer farming entities are also responsible for increased production areas in the commercial sector (Vink and Van Rooyen, 2009) but consolidation on smallholder schemes is more difficult to achieve (Manona et. al., 2010). The end-point of the trend on technically intensive smallholder schemes are state-driven initiatives, where all plots are consolidated into a single landholding entity and then 'leased' with infrastructure to a commercial partner. The partner typically farms independently, or in a nominal partnership with land-right holders involving their employment, explaining why it is called an equity-labourer scheme. This enterprise model should only be considered as a last resort, for existing schemes where infrastructure is still functional but the level of complexity has halted farming. Without exception, irrigation and development experts agree that this model should not be an option for new schemes or for conversion of existing schemes as part of revitalisation (Legoupil, 1985; Crosby et al., 2000; Vaughan, 1997; Laker, 2004). Yet, this model has been imposed on several scheme communities during the RECHARGE phase of the Limpopo RESIS programme and is also being used in revitalisation of dryland farming in KwaZulu-Natal and the Eastern Cape (Umhlaba, 2010b).

The situation on canal schemes which have not been reengineered is somewhat different. These canal schemes are typically older than 40 years and combined they contribute about $25 \%$ to the total smallholder irrigation scheme command area. Some of these schemes make an important contribution to the livelihoods of plot-holders (Mohamed, 2006). Low operating costs allow for farming approaches that are not by necessity driven primarily by the cash-economy, and this makes these schemes inclusive of farmers with meagre financial resources. Cash is not needed to pay monthly electricity bills as is the case 
on pumped schemes, or to drive professional farm-management arrangements as found in commercial partnerships. Canal schemes accommodate the full spectrum of farming objectives and permit farmers to choose between the use of local resources (manure, animal draught) and external resources (fertiliser and mechanisation) in the functioning of their farming system. Canal schemes tend to be more flexible and more stable than other types of schemes and are likely to support greater numbers of individuals, albeit on smaller plots, as consolidation is not essential for ongoing farming operations.

Implementation of a uniform model that relies on technically intensive and high-cost infrastructure to all types of schemes, without recognition of the varied requirements of groupings, effectively results in the elimination of Black smallholder farming enterprises and their replacement with single commercial entities. The irrigation scheme typology that has been developed provides guidance for the most suitable development trajectory for particular schemes. Identifying this trajectory and using it to engage farmers in deciding on ways to improve their schemes makes it possible to improve support to smallholder irrigators, with substantive returns on investment, both social and financial.

\section{Conclusions}

This review of research on smallholder irrigation schemes has provided evidence of the considerable knowledge base that has been generated by the WRC. Gaps in knowledge on human, economic and social aspects of irrigation were identified. Filling these gaps is expected to contribute to improved performance and greater sustainability of these projects. Generally, the picture of smallholder irrigation schemes painted by researchers has been rather bleak, but there has also been evidence of success. Most researchers have concluded that the impact of smallholder irrigation schemes on the livelihoods and wellbeing of irrigators has been limited, despite the substantial public investments that have been made to construct, maintain and revitalise these projects. Against a backdrop of water scarcity, the social and economic value of using smallholder irrigation schemes as an option for rural development in South Africa has been questioned, resulting in calls for the development focus to shift to dryland agriculture, because dryland farming has been shown to be hydrologically neutral (Inocencio et al., 2003; Hope et al., 2008). The authors do not concur. There is evidence that smallholder irrigation schemes have contributed positively to rural livelihoods and poverty alleviation in parts of the country that are most disadvantaged. The review demonstrated the considerable scope that exists to improve these projects and increase their contribution to local economic development. When dealing with these projects, policy-makers and implementers of such policy should consider the knowledge and guidelines that have been generated by the WRC to avoid repeating past mistakes.

The review identified the need to generate knowledge on other groups of Black irrigators, who operate outside the irrigation schemes. Home gardening has become an important topic in the portfolio of research projects of the WRC, but as yet independent irrigation farmers and irrigated communitygarden projects have not received attention.

\section{References}

ALIBER M and HART T (2009) Should subsistence agriculture be supported as a strategy to support rural food insecurity? Agrekon 48 (4) 434-458.
BACKEBERG GR (2003) Water usage and irrigation policy. In: Nieuwoudt L and Groenewald J (eds.) The Challenge of Change: Agriculture, Land and the South African Economy. University of Natal Press, Scottsville, South Africa. 149-170.

BACKEBERG GR (2006) Water institutional reforms in South Africa. Water Pol. 7 107-123.

BACKEBERG GR (2006) Reform of user charges, market pricing and management of water: problem or opportunity for irrigated agriculture. Irrig. Drain. 55 1-12.

BACKEBERG GR, BEMBRIDGE TJ, BENNIE ATP, GROENEWALD JA, HAMMES PS, PULLEN RA and THOMPSON H (1996) Policy Proposal for Irrigated Agriculture in South Africa. WRC Report No. KV96/96. Water Research Commission, Pretoria, South Africa. 119 pp.

BACKEBERG GR and GROENEWALD JA (1995a) A market directed approach for the efficient and equitable rehabilitation of government water schemes. In: Proc. Southern African Irrigation Symp. 4-6 June 1991, Durban. WRC Report No. TT 71/98. Water Research Commission, Pretoria, South Africa. 371-380.

BACKEBERG GR and GROENEWALD JA (1995b) Lessons from the economic history of irrigation development for smallholder settlement in South Africa. Agrekon 34 (3) 167-171.

BEINART W (2001) Twentieth-Century South Africa. Oxford University Press, Oxford. 414 pp.

BEMBRIDGE TJ (1984) A Systems Approach Study of Agricultural Development Problems in Transkei. Ph.D. thesis, University of Stellenbosch, Stellenbosch, South Africa. 685 pp.

BEMBRIDGE TJ (1987) Requirements for successful irrigation projects with special reference to the Tyefu Irrigation Scheme. Ciskei Agric. J. 5 10-16.

BEMBRIDGE TJ (1988) Considerations for successful irrigation schemes in developing areas. Ciskei Agric. J. 8 15-20.

BEMBRIDGE TJ (1997) Small-scale farmer irrigation in South Africa: Implications for extension. S. Afr. J. Agric. Ext. 26 71-81.

BEMBRIDGE T (2000) Guidelines for Rehabilitation of Small-Scale Farmer Irrigation Schemes in South Africa. WRC Report No. 891/1/00. Water Research Commission, Pretoria, South Africa. 163 pp.

BEMBRIDGE TJ and SEBOTJA I (1992) A comparative evaluation of aspects of the human impact of three irrigation schemes in Lebowa. S. Afr. J. Agric. Ext. 21 30-41.

BOLDING A (2004) In Hot Water: A Study on Sociotechnical Intervention Models and Practices of Water Use in Smallholder Agriculture, Nyanyadzi Catchment, Zimbabwe. Ph.D. thesis, Research School for Resource Studies for Development, Wageningen University, Wageningen, The Netherlands. 398 pp.

BRUWER J and VAN HEERDEN P (1995) Spotlights on irrigation development in RSA: The past, present and future. In: Proceedings of the Southern African Irrigation Symposium, 4-6 June 1991, Durban. WRC Report No. TT 71/98. Water Research Commission, Pretoria, South Africa. 3-10.

COLLINS J (1995) Farm size and non traditional exports: Determinants of participation in world markets. World Dev. 23 (7) 1103-1114.

CONRADIE B, ECKERT J, KLEYNHANS T and GRISSEL H (1996) Apple production systems by small-scale farmers in the Western Cape. Agrekon 35 (1) 1-11.

COMMISSION FOR THE SOCIO-ECONOMIC DEVELOPMENT OF THE BANTU AREAS WITHIN THE UNION OF SOUTH AFRICA (1955) Summary of the Report. The Government Printer, Pretoria, South Africa.

CROSBY CT, DE LANGE M, STIMIE CM and VAN DER STOEP I (2000) A Review of Planning and Design Procedures Applicable to Small-Scale Farmer Irrigation Projects. WRC Report No. 578/2/00. Water Research Commission, Pretoria, South Africa. 240 pp.

DE LANGE M (1994) Small Scale Irrigation in South Africa. WRC Report No. 578/1/94. Water Research Commission, Pretoria, South Africa. 29 pp.

DE LANGE M, ADENDORFF J and CROSBY CT (2000) Developing Sustainable Small-Scale Farmer Irrigation in Poor Rural Communities: Guidelines and Check Lists for Trainers and Development Facilitators. WRC Report No. 774/1/00. Water 
Research Commission, Pretoria, South Africa. 59 pp.

DENISON J and MANONA S (2007a) Principles, Approaches and Guidelines for the Participatory Revitalisation of Smallholder Irrigation Schemes: Volume 1 - A Rough Guide for Irrigation Development Practitioners. WRC Report No. TT 308/07. Water Research Commission, Pretoria, South Africa. 114 pp.

DENISON J and MANONA S (2007b) Principles, Approaches and Guidelines for the Participatory Revitalisation of Smallholder Irrigation Schemes: Volume 2 - Concepts and Cases. WRC Report No. TT 309/07. Water Research Commission, Pretoria, South Africa. $67 \mathrm{pp}$

DE WET C (2011) Where are they now? Welfare, development and marginalization in a former Bantustan settlement in the Eastern Cape, post-1994. In: Hebinck P and Shackleton C (eds.) Reforming Land and Resource Use in South Africa: Impacts on Livelihoods. Routledge, Milton Park, Abingdon, UK. 294-314.

DU PLESSIS FJ, VAN AVERBEKE W and VAN DER STOEP I (2002) Micro-Irrigation for Smallholders: Guidelines for Funders, Planners, Designers and Support Staff in South Africa. WRC Report No. TT 164/01. Water Research Commission, Pretoria, South Africa. $67 \mathrm{pp}$.

DU PLESSIS FJ and VAN DER STOEP I (2001) Evaluation of the Appropriateness and Management Requirements of MicroIrrigation Systems in Small-Scale Farming. WRC Report No. 768/1/01. Water Research Commission, Pretoria, South Africa. $167 \mathrm{pp}$.

FANADZO M, CHIDUZA C and MNKENI PNS (2009) Comparative response of direct seeded and transplanted maize (Zea mays L.) to nitrogen fertilization at Zanyokwe irrigation scheme, Eastern Cape, South Africa. Afr. J. of Agric. Res. 4 (8) 689-694.

FANADZO M, CHIDUZA C, MNKENI PNS, VAN DER STOEP I AND STEVENS J (2010) Crop production management practices as a cause for low water productivity at Zanyokwe Irrigation Scheme. Water SA 36 (1) 27-36.

FAURÈS, J-M, SVENDSEN, M and TURRAL, J (2007). Reinventing irrigation, In: Molden, D (ed.) Water for Food Water for Life: A Comprehensive Assessment of Water Management in Agriculture. Earthscan, London, UK. 353-394.

FEDER G (1985) The relationship between farm size and farm productivity: The role of family labour, supervision and credit constraints. J. Dev. Econ. 18 (2-3) 297-313.

HEBINCK P and VAN AVERBEKE W (2007) Rural transformations in the Eastern Cape. In: Hebinck, P and Lent PC (eds.) Livelihoods and Landscapes: The People of Guquka and Koloni and Their Resources. Afrika-Studiecentrum Series Vol. 9. Brill, Leiden, The Netherlands. 33-66.

HEBINCK P and MONDE N (2007) Production of crops in arable fields and home gardens. In: Hebinck, P and Lent PC (eds.) Livelihoods and Landscapes: The People of Guquka and Koloni and Their Resources. Afrika-Studiecentrum Series Vol. 9. Brill, Leiden, The Netherlands. 181-220.

HOLBROOK G (1996) Lessons to be learned from two irrigation schemes. Dev. S. Afr. 13 (4) 601-610.

HOLBROOK G (1998) Shoring up hydraulic despotism: Class, race and ethnicity in irrigation politics in the Eastern Cape Province, South Africa. J. Contemp. Afr. Stud. 1998 117-132.

HOPE RA, GOWING JW and JEWITT GPW (2008) The contested future of irrigation in African rural livelihoods - Analysis from a water scarce catchment in South Africa. Water Pol. 10 173-192.

HOUGHTON DH (1955) Life in the Ciskei: A Summary of the Findings of the Keiskammahoek Rural Survey 1947-51. SA Institute of Race Relations, Johannesburg, South Africa. 72 pp.

INOCENCIO A, SALLY H and MERREY DJ (2003) Innovative Approaches to Agricultural Water Use for Improving Food Security in Sub-Saharan Africa. IWMI Working Paper 55. International Water Management Institute, Colombo, Sri Lanka. $18 \mathrm{pp}$.

IPTRID (2000) Affordable Irrigation Technologies for Smallholders: Opportunities for Technology Adaptation and Capacity Building. FAO, Rome. 35 pp.

ISENEKE DEVELOPMENTS (2004) Potential of Sustainable Irrigation in Black Development Communities. WRC Report No.
1138/1/04. Water Research Commission, Pretoria, South Africa. $65 \mathrm{pp}$.

KAMARA A, VAN KOPPEN B and MAGINGXA L (2001) Economic viability of small-scale irrigation systems in the context of state withdrawal: The Arabie scheme in the Northern Province of South Africa. In: Proc. Second WARSFA/Waternet Symposium: Integrated Water Resource Management: Theory, Practice, Cases. October 30-31, 2001, Cape Town, South Africa. 116-128.

KHUVUTLU I and LAKER MC (1993) Identifying constraints and opportunities for farmers at middle Letaba Irrigation Project using a low cost appraisal approach. FSR-E S. Afr. Newsletter 5 6-16.

LAHIFF E (2000) An Apartheid Oasis? Agricultural and Rural Livelihoods in Venda. Frank Cass Publishers, London. 299 pp.

LAKER MC (2004) Development of a General Strategy for Optimizing the Efficient Use of Primary Water Resources for Effective Alleviation of Rural Poverty. WRC Report No. KV149/04. Water Research Commission, Pretoria, South Africa. $187 \mathrm{pp}$.

LANKFORD BA (2004) Irrigation improvement projects in Tanzania: Scale impacts and policy implications. Water Pol. 6 89-102.

LANKFORD BA and GILLINGHAM P (2001) The impacts of irrigation improvement programmes. Paper presented at the $1^{\text {st }}$ National Irrigation Conference, Morogoro, Tanzania. 20-22 March, 2001.

LEGOUPIL JC (1985) Some Comments and Recommendations about Irrigation Schemes in South Africa: Report of Mission, 11 February - 3 March 1985. Water Research Commission, Pretoria, South Africa. 35 pp.

LETSOALO SS and VAN AVERBEKE W (2005a) Sharing the water: Institutional and organisational arrangements at Dzindi Irrigation Scheme in South Africa. S. Afr. J. Agric. Ext. 34 (1) 34-43.

LETSOALO SS and VAN AVERBEKE W (2005b) Strategies for successful smallholder farmers' collective action: Case of Dzindi Irrigation Scheme. In: Proc. $39^{\text {th }}$ Annual Conference of the South African Society for Agricultural Extension. South African Society for Agricultural Extension, University of Pretoria, South Africa. 221-228.

LETSOALO SS and VAN AVERBEKE W (2006a) Infrastructural maintenance on smallholder canal irrigation schemes in the north of South Africa. Proc. International Symposium on Water and Land Management for Sustainable Irrigated Agriculture. 4-8 April 2006, Cukurova University, Adana, Turkey. [CD ROM].

LETSOALO SS and VAN AVERBEKE W (2006b) Water management on a smallholder canal irrigation scheme in South Africa. In: Perret S, Farolfi S and Hassan R (eds.) Water Governance for Sustainable Development: Approaches and Lessons from Developing and Transitional Countries. Earthscan, London. 93-109.

LIPTON M (1996) Rural reforms and rural livelihoods: The context of international experience. In: Lipton M, De Klerk M and Lipton M (eds.) Land, Labour and Livelihoods in Rural South Africa, Volume One: Western Cape. Indicator Press, Dalbridge, Durban, South Africa.

MANONA S, DENISON J, VAN AVERBEKE W and MASIYA T (2010) Proposed land tenure and land administration interventions to increase productivity on smallholder irrigation schemes in South Africa. Paper presented at 'Overcoming Inequality and Structural Poverty in South Africa: Towards Inclusive Growth and Development', 20-22 September 2010, Birchwood Hotel and Conference Centre, Johannesburg. URL: http://www.phuhlisani. com/oid\%5Cdownloads\%5CManona\%20et\%20al.pdf (Accessed 15 September 2011). 23 pp.

MACHETE CL, MOLLEL NM, AYISI K, MASHATOLA MB, ANIM FDK and VANASSCHE F (2004) Smallholder Irrigation and Agricultural Development in the Olifants River Basin of Limpopo Province: Management Transfer, Productivity, Profitability and Food Security Issues. WRC Report No. 1050/1/04. Water Research Commission, Pretoria, South Africa. 112 pp.

MAGINGXA LL, ALEMU ZG and VAN SCHALKWYK HD (2009) Factors influencing access to produce markets for smallholder irrigators in South Africa. Dev. S. Afr. 26 (1) 47-58.

MNKENI PNS, CHIDUZA C, MODI AT, STEVENS JB, MONDE N, VAN DER STOEP I and DLADLA RW (2010) Best Management Practices for Smallholder Farming on Two Irrigation Schemes 
in the Eastern Cape and KwaZulu-Natal through Participatory Adaptive Research. WRC Report No. TT 478/10. Water Research Commission, Pretoria, South Africa. 359 pp.

MOHAMED SS (2006) Livelihoods of Plot Holder Homesteads at the Dzindi Smallholder Canal Irrigation Scheme. D. Tech. (Agric.) thesis, Tshwane University of Technology, Pretoria, South Africa. $285 \mathrm{pp}$.

ORNE-GLIEMANN M (2008) Water users' associations from the users' perspective: Local water management at Thabina Irrigation Scheme, Limpopo, South Africa. J. Transdisciplinary Res. S. Afr. 4 (1) 1-29.

ORTMANN G and MACHETE C (2003) Problems and opportunities in South African agriculture. In: Nieuwoudt L and Groenewald J (eds.) The Challenge of Change: Agriculture, Land and the South African Economy. University of Natal Press, Scottsville, South Africa. 47-62.

PERRET S and TOUCHAIN E (2002) SMILE: A Simulation-Based Approach to Assess the Economic Viability of Smallholding Irrigation Schemes in South Africa: Conceptualisation and First Implementation. CIRAD -Tera num 02/02. University of Pretoria, South Africa. 24 pp.

RAMABULANA TR (2011) The rise of South African agribusiness: The good, the bad and the ugly. Agrekon 50 (2) 102-109.

REINDERS FB, VAN DER STOEP I, LECLER NL, GREAVES KR, VAHRMEIJER JT, BENADÉ N, DU PLESSIS FJ, VAN HEERDEN PS, STEYN JM, GROVÉ B, JUMMAN A and ASCOUGH G (2010) Standards and Guidelines for Improved Efficiency of Irrigation Water Use from Dam Wall Release to Root Zone Application: Guidelines. WRC Report No. TT 466/10. Water Research Commission, Pretoria, South Africa. 209 pp.

ROSSOUW JG (1989) The Impact of Imposed Technology on a Traditional Rural Society in Transkei: An Evaluation of the Ncora Irrigation Scheme. D.Sc. Agric. thesis, University of Fort Hare, Alice, South Africa. 547 pp.

SCOTNEY DM and VAN DER MERWE AJ (1995) Irrigation: Longterm viability of soil and water resources in South Africa. In: Proceedings of the Southern African Irrigation Symposium. 4-6 June 1991, Durban. WRC Report No. TT 71/98. Water Research Commission, Pretoria, South Africa. 50-60.

SHAH T, VAN KOPPEN B, MERREY D, DE LANGE M and SAMAD M (2002) Institutional Alternatives in African Smallholder Irrigation: Lessons from International Experience with Irrigation Management Transfer. IWMI Research Report 60. International Irrigation Management Institute, Colombo, Sri Lanka. 24 pp.

SPEELMAN S, D'HAESE M, BUYSSE J and D'HAESE L (2008) A Measure for the efficiency of water use and its determinants, a case study of small-scale irrigation schemes in North-West Province, South Africa. Agric. Syst. 98 31-39.

SPEELMAN S, FRIJA A, PERRET S, D'HAESE M, FAROLFI S and D'HAESE L (2011) Variability in smallholders' irrigation water values: Study in North-West Province, South Africa. Irrig. Drain. 60 11-19.

STATISTICS SA (2011) Consumer Price Index (PO141) Metropolitan Areas - All Items. URL: www.statssa.gov.za/keyindicators/cpi.asp.
THE COMMISSION OF ENQUIRY OF ENQUIRY APPOINTED BY THE EASTERN CAPE PROVINCE TO LOOK FOR SUSTAINABLE SOLUTIONS TO THE PROBLEMS OF LARGE EASTERN CAPE IRRIGATION SCHEMES (1996) Ncora Irrigation Scheme: Summary Report. Faculty of Agriculture and ARDRI, University of Fort Hare, Alice, South Africa. 16 pp.

TLOU T, MOSAKA D, PERRET S, MULLINS D and WILLIAMS CJ (2006) Investigation of Different Farm Tenure Systems and Support Structure for Establishing Small-Scale Irrigation Farmers in Long Term Viable Conditions. WRC Report No. 1353/1/06. Water Research Commission, Pretoria, South Africa. 174 pp.

TURRAL H, SVENDSEN M and FAURES JM (2010) Investing in irrigation: Reviewing the past and looking to the future. Agric. Water Manage. 97 551-560.

UMHLABA (2010a) Smallholder Irrigation Development Guidelines. WRC Report No. TT 449/10, Water Research Commission, Pretoria, South Africa.

UMHLABA (2010b) A Review of Experiences of Establishing Emerging Farmers in South Africa: Case Lessons and Implications for Farmer Support within Land Reform Programmes. FAO, Rome, Italy. $81 \mathrm{pp}$.

VAN AVERBEKE W (2008) Best Management Practices for Sustainable Subsistence Farming on Selected Irrigation Schemes and Surrounding Areas through Participatory Adaptive Research in Limpopo Province. WRC Report No. TT 344/08. Water Research Commission, Pretoria, South Africa. 318 pp.

VAN AVERBEKE W, M'MARETE CK, IGODAN CO and BELETE A (1998) An Investigation into Plot Production at Irrigation Schemes in Central Eastern Cape. WRC Report No. 719/1/98. Water Research Commission, Pretoria, South Africa. 206 pp.

VAN AVERBEKE W and MOHAMED SS (2006) Smallholder farming styles and development policy in South Africa: The case of Dzindi irrigation scheme. Agrekon 45 (2) 136-157.

VAN DER STOEP I (2011) Irrigation Water Measurement - From Voluntary Management to Pending Regulations. Paper presented at the Water Research Commission 40-Year Celebration Conference. 31 August - 1 September 2011, Kempton Park, South Africa. URL: www.wrc.org.za/Pages/KH ConferenceProceedings

VAUGHAN A (1997) Irrigation Development - Current Realities, New Policies, and Future Possibilities for Positive Impacts on Rural Poverty. Institute for Social and Economic Research, University of Durban-Westville, Durban, South Africa. 18 pp.

VERMILLION DL (1997) Impacts of Irrigation Management Transfer: A Review of the Evidence. IWMI Research Report 11. International Irrigation Management Institute, Colombo, Sri Lanka. 34 pp.

VINK N and KIRSTEN J (2003) Agriculture in the national economy. In: Nieuwoudt L and Groenewald J (eds.) The Challenge of Change: Agriculture, Land and the South African Economy. University of Natal Press, Scottsville, South Africa. 3-19.

VINK N and VAN ROOYEN J (2009) The Economic Performance of Agriculture in South Africa since 1994: Implications for Food Security. Working Paper No 17. Development Planning Division, Development Bank of Southern Africa, Halfway House, South Africa. 38 pp.

YOKWE S (2009) Water productivity in smallholder irrigation schemes in South Africa. Agric. Water Manage. 96 1223-1228. 